\title{
Global toxocariasis research trends from 1932 to 2015: a bibliometric analysis
}

Sa'ed H. Zyoud ${ }^{1,2}$

\begin{abstract}
Background: Toxocariasis is a highly prevalent parasitic disease in the tropical regions of the world, with its impact on public health being typically underestimated. To better recognise the trends and characteristics of toxocariasis research, this study is a bibliometric analysis of the global toxocariasis research.

Methods: Searches were completed on April 5, 2016, using the Scopus database. A search without any language restriction was performed to extract publications dealing with toxocariasis. Terms related to toxocariasis were used to perform a title keyword search.

Results: A total of 2765 publications comprising 11 document types and published between 1932 and 2015 were included in the analysis. Articles were the most popular document form, accounting for $83.62 \%$ of all publications, followed by letters (3.80\%) and reviews (3.4\%). The annual number of research publications increased from 30 in 1980 to 111 in 2015, indicating that the number of publications on toxocariasis has increased slowly over the past 35 years. The United States of America and Japan are the predominant countries of origin, with 303 articles and 207 articles, respectively, followed by Brazil and the United Kingdom, with 180 (6.5\%) each. The $h$-index for all the publications was 60. The highest $h$-index were for publications from the United Kingdom $(h$-index value $=43)$ and the United States ( $h$-index value $=39$ ); these two countries were also involved with the highest number of international collaborations, with 27 and 28 countries, respectively.

Conclusions: Developed countries, including the United States, Japan, the United Kingdom, France, Germany and Italy, are the world's leaders in toxocariasis research, contributing to more than $34 \%$ of the total published literature. In addition, developing countries, such as Brazil, Poland, Argentina and India, showed a noticeable increase in published papers on toxocariasis research in recent years. A push for more collaboration is needed to achieve a superior research strategy related to toxocariasis at the global level from the viewpoint of epidemiological data, clinical aspects, medical ecology, molecular aspects and treatment practices associated with toxocariasis.
\end{abstract}

Keywords: Toxocariasis, Toxocara, Bibliometric, Scopus, Citations

\section{Background}

Toxocariasis is a highly prevalent parasitic disease in the tropical regions of the world, with its impact on public health being typically underestimated [1-3]. Human toxocariasis is acquired by ingestion of Toxocara canis or Toxocara cati embryonated eggs present in the soil or on hands and fomites contaminated by the faeces of infected dogs or cats; thus, it is considered to be a

\footnotetext{
Correspondence: saedzyoud@yahoo.com; saedzyoud@najah.edu

'Division of Clinical and Community Pharmacy, Department of Pharmacy,

Faculty of Medicine and Health Sciences, An-Najah National University,

Nablus 44839, Palestine

${ }^{2}$ Poison Control and Drug Information Center (PCDIC), Faculty of Medicine and Health Sciences, An-Najah National University, Nablus 44839, Palestine
}

widespread zoonotic parasitic disease $[1,4]$. Toxocara specimens were first illustrated by Werner in 1782; however, the genus was not recognized until 1905 by Stiles [5]. The clinical symptoms of toxocariasis in humans may vary from asymptomatic infection to localized symptoms (ocular and neurological) or severe systemic infection (visceral larva migrans), which is commonly complicated by blood eosinophilia [6-8].

Several studies have concluded that the cost of human toxocariasis is underestimated and understanding of its global impact remains poor because of the inadequacy of clinical awareness and an obvious lack of efficacy of laboratory, clinical and treatment interventions $[1,2,4$, 
9-11]. To the author's knowledge, to date, no bibliometric studies have assessed Toxocara and toxocariasis research over time at the global level. The bibliometric technique has already been applied to infectious diseases such as Mayaro [12], Zika [13], Chikungunya [14], leishmaniasis [15], malaria [16, 17], dengue [18, 19], Ebola [20], Middle East respiratory syndrome coronavirus [21] and Giardia lamblia [22].

Bibliometric analyses based on measuring the yearly publication output, publication types, source countries with their $h$-index, international collaboration research, source journals with their impact factors (IFs), and citation patterns are widely used by research funders or universities to assess research performance and to shed new light on future research trends. To better recognise the trends and characteristics of toxocariasis research, this study was designed to analyse the global toxocariasis research through bibliometric analysis.

\section{Methods}

The method of this study was derived from those of previous similar studies [17, 23-25]. Searches were completed in April 5, 2016, using the Scopus database. A search without any language restriction was performed to extract publications dealing with toxocariasis. Scopus published by Elsevier is known to be the most common source of data for bibliometric studies in the sciences [17, 25-27]. Compared with other databases, such as PubMed or Web of Knowledge, its records provide more comprehensive coverage [28] of the toxocariasis literature. The terms "toxocar", "nematode ophthalmitis", "visceral larva migrans", "ocular larva migrans", "Nematode endophthalmitis", "dog roundworm" and "cat roundworm" were used as keywords to search titles. These keywords were based on previous review articles [6, 29-31]. The asterisk (*) was applied as a wildcard and enabled the search for variations of key terms. For example, entering "toxocar" in the Scopus search engine would include the following terms: toxocariasis, toxocara - briefly, any probable word that might start with the seven letters (i.e. 'toxocar'). Therefore, searching only titles would have resulted in data more related to the field of toxocariasis. No time period restriction was designated in the search concerning the start date, thus all publications prior to December 31, 2015, were included. In this study, a traditional bibliometric technique that included analysis of yearly publication output, languages, publication types, countries with their $h$-index, international collaboration research, source journals with their IFs, citation patterns and institutes was used. Documents published in 2016 or errata were excluded from the analysis. IFs were retrieved from the Journal Citation Reports (JCR 2014) [32]. The values of the $h$-index were extracted from the Scopus database for each country.

\section{Ethical issues}

The analysis in this study is based on a retrospective bibliometric technique; therefore, no ethical approval was required.

\section{Statistical analysis}

Microsoft Excel $^{\bullet}$ and version 15 of SPSS $^{\circ}$ for Windows were used to perform statistical analysis. These software packages were used to generate data on frequency distribution, percentage, sum and average, and to create Fig. 1. Further analysis was introduced to obtain the top tenranked prolific countries, most prolific journals, most prolific institutions and most cited papers by using the 1-2-2-4 rule, which is known as the standard competition ranking.

\section{Results}

A total of 2765 publications comprising 11 document types published between 1932 and 2015 were found. Articles were the most popular type of document, accounting for $83.62 \%$ of all the publications, followed by letters $(3.80 \%)$ and reviews $(3.4 \%)$. Of the 29 different languages identified, English (73.4\%), Spanish (4.5\%), French (4.5\%), German (3.4\%) and Polish (3.0\%) were predominant. Figure 1 presents the distribution of publications on toxocariasis during the period of 1932-2015. The annual number of research publications increased from 30 in 1980 to 111 in 2015, showing that the number of publications on toxocariasis has increased slowly over the past 35 years.

Concerning the country of publication, 97 countries with publications on toxocariasis were identified. Table 1 shows the top 10 countries in descending order of publication number. The United States of America and Japan were the predominant countries, with 303 and 207 articles, respectively, followed by Brazil and the United Kingdom with 180 (6.5\%) each. The $h$-index for all the publications was 60 . The highest $h$-index were for publications from the United Kingdom ( $h$-index value $=43$ ) and the United States $(h$-index value $=39)$. The United States and the United Kingdom participated in the highest number of international collaborations, with 28 and 27 countries, respectively. In terms of the rate of publications from international collaborative research to total research for each country, the United Kingdom and Germany (28.9\% and $25.3 \%$, respectively) were the most active.

Table 2 lists the 10 journals with the highest number of published documents referring to toxocariasis research from 1932 to 2015, with their IF. Veterinary Parasitology published the most documents (96, 3.47\%), 


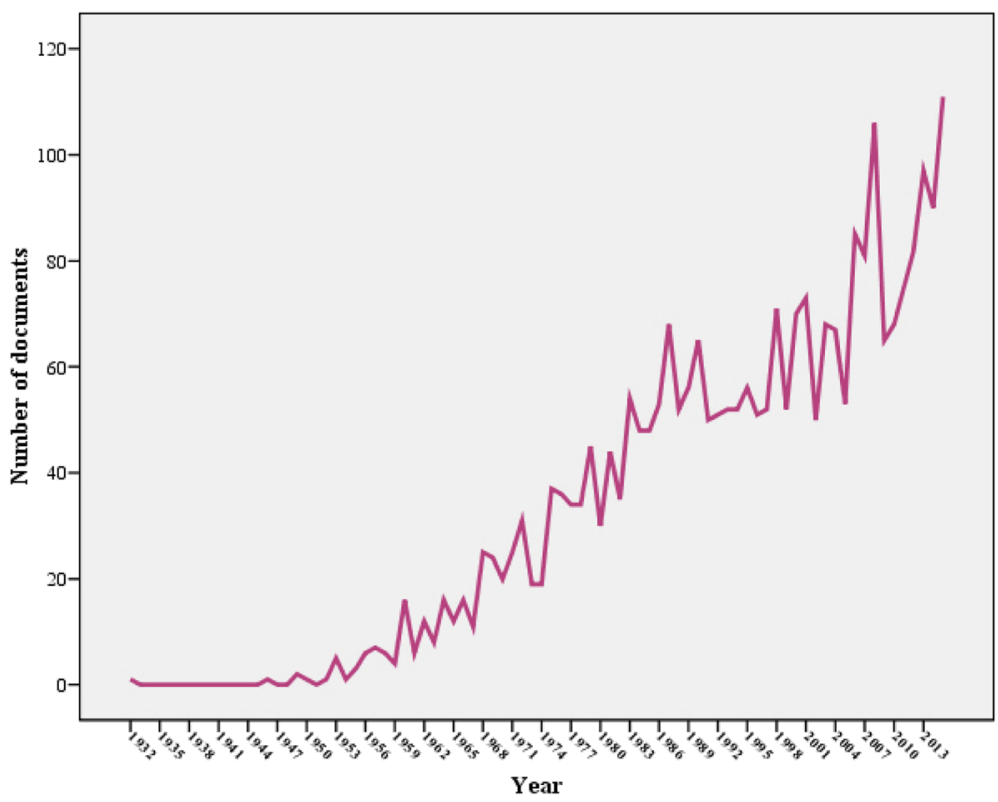

Fig. 1 World Scopus publications with toxocariasis during 1932-2015

followed by Journal of Helminthology (82), Revista do Instituto De Medicina Tropical De Sao Paulo (58) and Parasitology Research (57), which had IFs of 2.460, $1.421,1.007$ and 2.098, respectively. The top 10 subject categories worldwide, with greater than 15 publications, are shown in Table 3. Medicine comprised $64.4 \%$ articles,

Table 1 The 10 most productive countries in toxocariasis research

\begin{tabular}{llllll}
\hline SCR $^{a}$ Country & $\begin{array}{l}\text { Number of } \\
\text { documents } \\
(\%)\end{array}$ & $\begin{array}{l}h \text {-index } \\
\text { (5) }\end{array}$ & $\begin{array}{l}\text { Collaborations } \\
\text { with foreign } \\
\text { countries }\end{array}$ & $\begin{array}{l}\text { The number }(\%)^{b} \\
\text { of publications } \\
\text { with international } \\
\text { collaboration }\end{array}$ \\
\hline States & $303(11.0)$ & 39 & 28 & $43(14.2)$ \\
2nd Japan & $207(7.5)$ & 27 & 19 & $33(15.9)$ \\
3rd & Brazil & $180(6.5)$ & 23 & 10 & $16(8.9)$ \\
3rd & $\begin{array}{l}\text { United } \\
\text { Kingdom }\end{array}$ & $180(6.5)$ & 34 & 27 & $52(28.9)$ \\
5th France & $115(4.2)$ & 22 & 10 & $14(12.2)$ \\
6th Germany & $79(2.9)$ & 16 & 14 & $20(25.3)$ \\
7th Poland & $78(2.8)$ & 14 & 5 & $11(14.1)$ \\
8th Italy & $61(2.2)$ & 14 & 8 & $10(16.4)$ \\
9th Argentina & $59(2.1)$ & 15 & 2 & $2(3.4)$ \\
10th India & $57(2.1)$ & 8 & 2 & $2(3.5)$
\end{tabular}

${ }^{a}$ Equal countries have the same ranking number, and then a gap is left in the ranking numbers

${ }^{b}$ Percentage of publications with international collaboration from the total number of publications for each country

c"International collaboration" defined as a document with at least two authors from different countries

SCR Standard competition ranking followed by Immunology and Microbiology with $36.1 \%$, and Veterinary with $13.1 \%$.

Table 4 presents the 20 most commonly cited toxocariasis publications between 1932 and 2015 [33-52]. The IFs varied from 1.151 for the 4th most cited paper to 45.217 for the 9th most cited paper. The total number of citations per publication in this table ranged from 108 to 477. The most frequently cited article was published in Journal of Clinical Investigation by Del Prete et al. [37] from Italy, which had been cited 477 times.

Table 2 Top 10 most productive journals, 1932-2015

\begin{tabular}{|c|c|c|c|}
\hline $\mathrm{SCR}^{\mathrm{a}}$ & Journal & $\begin{array}{l}\text { Number of } \\
\text { documents (\%) }\end{array}$ & IF \\
\hline 1 st & Veterinary Parasitology & $96(3.47)$ & 2.460 \\
\hline 2nd & Journal of Helminthology & $82(2.97)$ & 1.421 \\
\hline $3 r d$ & $\begin{array}{l}\text { Revista do Instituto De Medicina } \\
\text { Tropical De Sao Paulo }\end{array}$ & $58(2.10)$ & 1.007 \\
\hline 4 th & Parasitology Research & $57(2.06)$ & 2.098 \\
\hline 5th & $\begin{array}{l}\text { American Journal of Tropical } \\
\text { Medicine and Hygiene }\end{array}$ & $49(1.77)$ & 2.699 \\
\hline 6th & Journal of Parasitology & $45(1.63)$ & 1.227 \\
\hline 7th & $\begin{array}{l}\text { Transactions of the Royal Society } \\
\text { of Tropical Medicine and Hygiene }\end{array}$ & $37(1.34)$ & 1.839 \\
\hline 7th & $\begin{array}{l}\text { Journal of the Egyptian Society } \\
\text { of Parasitology }\end{array}$ & $37(1.34)$ & NA \\
\hline 9th & Parasite Immunology & $36(1.30)$ & 2.143 \\
\hline 10th & Parasitology & $35(1.27)$ & 2.560 \\
\hline
\end{tabular}

${ }^{a}$ Equal journals have the same ranking number, and then a gap is left in the ranking numbers

SCR Standard competition ranking, NA Not available, IF Impact factor 
Table 3 The top 10 most subject categories in the field of toxocariasis during the study period

\begin{tabular}{lll}
\hline SCR & Subject category & $\begin{array}{l}\text { Number of } \\
\text { documents (\%) }\end{array}$ \\
\hline 1st & Medicine & $1780(64.4)$ \\
2nd & Immunology and Microbiology & $998(36.1)$ \\
3rd & Veterinary & $362(13.1)$ \\
4th & Agricultural and Biological Sciences & $340(12.3)$ \\
5 th & Biochemistry, Genetics and & $128(4.6)$ \\
& Molecular Biology & \\
6th & Neuroscience & $79(2.9)$ \\
7th & Pharmacology, Toxicology and & $57(2.1)$ \\
& Pharmaceutics & $28(1.0)$ \\
8th & Health Professions & $17(0.6)$ \\
9th & Environmental Science & $15(0.5)$ \\
10th & Chemistry &
\end{tabular}

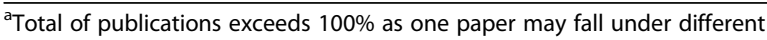
subject categories

SCR Standard competition ranking

Table 5 summarizes the top 10 productive institutes. Among them, two were from Brazil, and one each from Slovakia, Ireland, the Netherlands, Germany, Japan, the United States, the United Kingdom, Australia and Sri Lanka. The Instituto de Medicina Tropical de Sao Paulo was ranked 1st in institutional productivity with 44 scientific research publications, followed by the Parasitological Institute of the Slovak Academy of Sciences with 41 articles and the Universidade de Sao Paulo with 40.

\section{Discussion}

The current bibliometric study investigated the global toxocariasis research trends from 1932 to 2015. A bibliometric analysis of the patterns of publication outputs, publication types, journals with their IFs, source countries with their $h$-indexes, international collaboration research, institutional distributions and most-cited articles were conducted.

As shown in the current study, the annual number of research publications increased from 30 in 1980 to 111 in 2015, showing that the number of publications on toxocariasis has increased slowly in the past 35 years. An increase in research output has also been shown in similar research related to infectious diseases such as leishmaniasis [15], malaria [53] and Chagas disease [54]. In a comparison of the number of publications since 1980 concerning toxocariasis, leishmaniasis, malaria and Chagas disease, more rapid growth was observed in the number of papers focusing on leishmaniasis, of which 22,154 publications were published, followed by malaria (36,303 publications) and Chagas disease (5103 publications) compared with toxocariasis, on which 2281 publications were published. From this, it was concluded that, while there was a relative increase in research output in the field of toxocariasis since 1980, there was a higher interest in leishmaniasis, malaria and Chagas disease than in toxocariasis during this time period. This difference in interest between different issues can be attributed to discrepancies in the funding available for different diseases.

Developed countries, including the United States, Japan, the United Kingdom, France, Germany and Italy, are leading countries in toxocariasis research, contributing to more than $34 \%$ of the world's total publications. Possible explanations for these findings may be rapid economic growth or the progress of scientific research systems in these countries. These findings were similar to those reported in earlier bibliometric studies [55-57], which found that the economic growth of a country affected the quantity of research published by its researchers. Developing countries, such as Brazil, Poland, Argentina and India, showed a noticeable increase in published papers on toxocariasis research in recent years, which may have been coincident with a high prevalence of toxocariasis in these countries [31, 58-60]. The United States and the United Kingdom had the highest number of collaborations. Multinational collaboration can help to draw attention to toxocariasis research. Another advantage of this collaboration would be that internationally collaborative publications are usually cited more often than those from individual countries [57, 61].

The most cited article, by Del Prete et al. [37] in 1991, was cited 477 times. This Italian study demonstrated that, in human, the $\mathrm{T}$ cell response to $T$. canis comes from the stimulation of T-helper type 2 cell type by the "excretory-secretory" antigens of T. canis [37]. The second most cited article was by Despommier [38] in 2003, and looked at epidemiology, clinical and molecular aspects of toxocariasis and the medical ecology associated with the disease.

To date, this is the first bibliometric study to assess the output of peer-reviewed publications on toxocariasis at the global level. Previous bibliometric studies have stated the limitations characteristic of using such an approach [23, 24, 26, 27, 62-64]. First, the publications might not have been included in the analysis if toxocariasis or its related words were not mentioned in their titles, although these terms might have been found in the text. A second limitation was that this study did not include publications on toxocariasis that were in non-indexed journals and thus would not have been available in the Scopus database, such as those published in some Chinese journals.

\section{Conclusions}

This is the first study that investigated the global toxocariasis research trends from 1932 to 2015. The findings 
Table 4 The 20 most frequently cited publications related to toxocariasis from 1932 to 2015

\begin{tabular}{|c|c|c|c|c|c|}
\hline SCR & Authors (year of publication) & Title & Source title & Cited by & IF \\
\hline $1 s t$ & Del Prete et al. [37] & $\begin{array}{l}\text { "Purified protein derivative of Mycobacterium } \\
\text { tuberculosis and excretory-secretory antigen(s) } \\
\text { of toxocara canis expand in vitro human T } \\
\text { cells with stable and opposite (type } 1 \text { T helper } \\
\text { or type } 2 \text { T helper) profile of cytokine production" }\end{array}$ & Journal of Clinical Investigation & 477 & 13.215 \\
\hline 2nd & Despommier [38] & $\begin{array}{l}\text { "Toxocariasis: Clinical aspects, epidemiology, } \\
\text { medical ecology, and molecular aspects" }\end{array}$ & Clinical Microbiology Reviews & 364 & 17.406 \\
\hline $3 r d$ & Glickman and Schantz [41] & $\begin{array}{l}\text { "Epidemiology and pathogenesis of zoonotic } \\
\text { toxocariasis" }\end{array}$ & Epidemiologic Reviews & 303 & 6.667 \\
\hline 4 th & Magnaval et al. [44] & "Highlights of human toxocariasis" & Korean Journal of Parasitology & 248 & 1.151 \\
\hline 5 th & Beaver et al. [34] & $\begin{array}{l}\text { "Chronic eosinophilia due to visceral larva } \\
\text { migrans; report of three cases" }\end{array}$ & Pediatrics & 243 & 5.473 \\
\hline 6th & De Savigny [35] & $\begin{array}{l}\text { "In vitro maintenance of Toxocara canis larvae } \\
\text { and a simple method for the production of } \\
\text { Toxocara ES antigen for use in serodiagnostic } \\
\text { tests for visceral larva migrans" }\end{array}$ & Journal of Parasitology & 225 & 1.227 \\
\hline 7th & Schantz [49] & "Toxocara larva migrans now" & $\begin{array}{l}\text { American Journal of Tropical } \\
\text { Medicine and Hygiene }\end{array}$ & 188 & 2.699 \\
\hline 8th & De Savigny et al. [36] & $\begin{array}{l}\text { "Toxocariasis: Serological diagnosis by enzyme } \\
\text { immunoassay" }\end{array}$ & Journal of Clinical Pathology & 164 & 2.915 \\
\hline 9th & Taylor et al. [51] & "The expanded spectrum of toxocara disease" & The Lancet & 153 & 45.217 \\
\hline 10th & Magnaval et al. [43] & $\begin{array}{l}\text { "Application of the Western blotting procedure } \\
\text { for the immunodiagnosis of human toxocariasis" }\end{array}$ & Parasitology Research & 144 & 2.098 \\
\hline 11th & Overgaauw [46] & $\begin{array}{l}\text { "Aspects of toxocara epidemiology: Human } \\
\text { toxocarosis" }\end{array}$ & Critical Reviews in Microbiology & 134 & 6.020 \\
\hline 12th & Shields [50] & "Ocular toxocariasis. A review" & Survey of Ophthalmology & 131 & 3.849 \\
\hline 13th & Wilder [52] & "Nematode endophthalmitis" & $\begin{array}{l}\text { Transactions-American Academy of } \\
\text { Ophthalmology and Otolaryngology }\end{array}$ & 130 & NA \\
\hline 14th & Jacquier et al. [42] & $\begin{array}{l}\text { "Immunodiagnosis of toxocarosis in humans: } \\
\text { Evaluation of a new enzyme-linked } \\
\text { immunosorbent assay kit" }\end{array}$ & Journal of Clinical Microbiology & 119 & 3.993 \\
\hline 15th & Rubinsky-Elefant et al. [48] & $\begin{array}{l}\text { "Human toxocariasis: Diagnosis, worldwide } \\
\text { seroprevalences and clinical expression of } \\
\text { the systemic and ocular forms" }\end{array}$ & $\begin{array}{l}\text { Annals of Tropical Medicine } \\
\text { and Parasitology }\end{array}$ & 118 & 1.656 \\
\hline 16th & Barriga [33] & $\begin{array}{l}\text { "A critical look at the importance, prevalence } \\
\text { and control of toxocariasis and the possibilities } \\
\text { of immunological control" }\end{array}$ & Veterinary Parasitology & 117 & 2.460 \\
\hline 17th & Fisher [39] & $\begin{array}{l}\text { "Toxocara cati: An underestimated zoonotic } \\
\text { agent" }\end{array}$ & Trends in Parasitology & 116 & 6.204 \\
\hline 18th & Glickman et al. [40] & $\begin{array}{l}\text { "Evaluation of serodiagnostic tests for visceral } \\
\text { larva migrans" }\end{array}$ & $\begin{array}{l}\text { American Journal of Tropical Medicine } \\
\text { and Hygiene }\end{array}$ & 114 & 2.699 \\
\hline 19th & Overgaauw [47] & $\begin{array}{l}\text { "Aspects of Toxocara epidemiology: Toxocarosis } \\
\text { in dogs and cats" }\end{array}$ & Critical Reviews in Microbiology & 110 & 6.020 \\
\hline 20th & Maizels et al. [45] & $\begin{array}{l}\text { "Characterization of surface and excretory- } \\
\text { secretory antigens of Toxocara canis } \\
\text { infective larvae" }\end{array}$ & Parasite Immunology & 108 & 2.143 \\
\hline
\end{tabular}

SCR Standard competition ranking, NA Not available, IF Impact factor

indicated that the number of articles published annually increased slowly. Developed countries, including the United States, Japan, the United Kingdom, France, Germany, and Italy, are leading countries in toxocariasis research, contributing to more than $34 \%$ of the world's total publications. In addition, developing countries, such as Brazil, Poland, Argentina and India, demonstrated a noticeable increase in the number of publications related to toxocariasis in recent years. The United States is the world's leading country in research on toxocariasis and international scientific collaborations on this disease. It is necessary to encourage and support research on toxocariasis in other areas of the world. A push for increased collaboration is needed to achieve a superior research 
Table 5 The top 10 productive institutes in toxocariasis research

\begin{tabular}{|c|c|c|c|}
\hline $\mathrm{SCR}^{\mathrm{a}}$ & Institute & Country & $\begin{array}{l}\text { Number of } \\
\text { documents (\%) }\end{array}$ \\
\hline $1 s t$ & $\begin{array}{l}\text { Instituto de Medicina Tropical } \\
\text { de Sao Paulo }\end{array}$ & Brazil & $44(1.59)$ \\
\hline 2nd & $\begin{array}{l}\text { Parasitological Institute of the } \\
\text { Slovak Academy of Sciences }\end{array}$ & Slovakia & $41(1.48)$ \\
\hline $3 r d$ & Universidade de Sao Paulo-USP & Brazil & $40(1.45)$ \\
\hline 4th & Trinity College Dublin & Ireland & $32(1.16)$ \\
\hline 5 th & $\begin{array}{l}\text { National Institute of Public } \\
\text { Health and the Environment }\end{array}$ & Netherlands & $31(1.12)$ \\
\hline 6th & $\begin{array}{l}\text { Tierarztliche Hochschule } \\
\text { Hannover }\end{array}$ & Germany & $25(0.90)$ \\
\hline 7th & University of Miyazaki & Japan & $22(0.80)$ \\
\hline 7th & Cornell University & United States & $22(0.80)$ \\
\hline 9th & $\begin{array}{l}\text { London School of Hygiene \& } \\
\text { Tropical Medicine }\end{array}$ & United Kingdom & $21(0.76)$ \\
\hline 10th & University of Queensland & Australia & $20(0.72)$ \\
\hline 10th & University of Peradeniya & Sri Lanka & $20(0.72)$ \\
\hline
\end{tabular}

${ }^{a}$ Equal institutes have the same ranking number, and then a gap is left in the ranking numbers

SCR Standard competition ranking

strategy related to toxocariasis at the global level from the viewpoints of epidemiological data, clinical aspects, medical ecology, molecular aspects, and treatment practices associated with toxocariasis. Moreover, the search queries in the current area are biased toward publications in the English language. Therefore, it is important to know that most publications from China may be written in a language other than English, which limits access to these publications for non-Chinese speakers; this may have led to an underestimation of the research activities in nonEnglish countries such as China.

\section{Abbreviations}

IF: impact factor

\section{Acknowledgements}

None.

\section{Funding}

No funding was received for writing this study.

Availability of data and materials

Not applicable.

\section{Authors' contributions}

SZ conceptualized the study, acquired and processed the data, performed statistical analysis, and wrote and approved the final manuscript.

\section{Competing interests}

The author declares that he has no competing interests.

\section{Consent for publication}

Not applicable.

\section{Ethics approval and consent to participate}

The analysis in this study is based on a retrospective bibliometric technique; therefore, no ethical approval was required.

Received: 5 September 2016 Accepted: 14 February 2017

Published online: 23 February 2017

\section{References}

1. Moreira GM, Telmo Pde L, Mendonca M, Moreira AN, McBride AJ, Scaini CJ, Conceicao FR. Human toxocariasis: current advances in diagnostics, treatment, and interventions. Trends Parasitol. 2014;30:456-64.

2. Smith H, Holland C, Taylor M, Magnaval JF, Schantz P, Maizels R. How common is human toxocariasis? Towards standardizing our knowledge. Trends Parasitol. 2009;25:182-8.

3. Holland CV. Knowledge gaps in the epidemiology of Toxocara: the enigma remains. Parasitology. 2017;144(1):81-94

4. Macpherson CN. The epidemiology and public health importance of toxocariasis: a zoonosis of global importance. Int J Parasitol. 2013:43:999-1008.

5. Nicoletti A. Toxocariasis. In: Garcia HH, Tanowitz HB, Del Brutto OH, editors. Neuroparasitology and Tropical Neurology, Handb Clin Neurol, vol. 114. 2013. p. 217-28.

6. Kuenzli E, Neumayr A, Chaney M, Blum J. Toxocariasis-associated cardiac diseases - A systematic review of the literature. Acta Trop. 2016;154:107-20.

7. Gavignet B, Piarroux R, Aubin F, Millon L, Humbert P. Cutaneous manifestations of human toxocariasis. J Am Acad Dermatol. 2008:59:1031-42.

8. Van Den Broucke S, Kanobana K, Polman K, Soentjens P, Vekemans M, Theunissen C, Vlieghe E, Van Esbroeck M, Jacobs J, Van Den Enden E, et al. Toxocariasis diagnosed in international travelers at the Institute of Tropical Medicine, Antwerp, Belgium, from 2000 to 2013. PLoS Negl Trop Dis. 2015;9: e0003559.

9. Cong W, Zhang XX, Zhou N, Yu CZ, Chen J, Wang XY, Li B, Qian AD, Zhu $X Q$. Toxocara seroprevalence among clinically healthy individuals, pregnant women and psychiatric patients and associated risk factors in Shandong Province, Eastern China. PLoS Negl Trop Dis. 2014;8:e3082.

10. Janecek E, Wilk E, Schughart K, Geffers R, Strube C. Microarray gene expression analysis reveals major differences between Toxocara canis and Toxocara cati neurotoxocarosis and involvement of T. canis in lipid biosynthetic processes. Int J Parasitol. 2015;45:495-503.

11. de Almeida Carvalho EA, Rocha RL. Visceral larva migrans syndromes associated with toxocariasis: epidemiology, clinical and laboratory aspects of human toxocariasis. Curr Trop Med Rep. 2014;1:74-9.

12. Patino-Barbosa AM, Bedoya-Arias JE, Cardona-Ospina JA, Rodriguez-Morales AJ. Bibliometric assessment of the scientific production of literature regarding Mayaro. J Infect Public Health. 2016;9:532-4.

13. Martinez-Pulgarin DF, Acevedo-Mendoza WF, Cardona-Ospina JA, Rodriguez-Morales AJ, Paniz-Mondolfi AE. A bibliometric analysis of global Zika research. Travel Med Infect Dis. 2016;14:55-7.

14. Vera-Polania F, Munoz-Urbano M, Banol-Giraldo AM, Jimenez-Rincon M, Granados-Alvarez S, Rodriguez-Morales AJ. Bibliometric assessment of scientific production of literature on chikungunya. J Infect Public Health. 2015:8:386-8.

15. Ramos JM, Gonzalez-Alcaide G, Bolanos-Pizarro M. Bibliometric analysis of leishmaniasis research in Medline (1945-2010). Parasit Vectors. 2013;6:55.

16. Fu H, Hu T, Wang J, Feng D, Fang H, Wang M, Tang S, Yuan F, Feng Z. A bibliometric analysis of malaria research in China during 2004-2014. Malar J. 2015;14:195.

17. Sweileh WM, Sawalha AF, Al-Jabi SW, Zyoud SH, Shraim NY, Abu-Taha AS. A bibliometric analysis of literature on malaria vector resistance: (1996-2015). Glob Health. 2016;12:76.

18. Vera-Polania F, Perilla-Gonzalez Y, Martinez-Pulgarin DF, BaqueroRodriguez JD, Munoz-Urbano M, Lagos-Gallego M, Lagos-Grisales GJ, Villegas S, Rodriguez-Morales AJ. Bibliometric assessment of the LatinAmerican contributions in dengue. Recent Pat Antiinfect Drug Discov. 2014;9:195-201.

19. Zyoud SH. Dengue research: a bibliometric analysis of worldwide and Arab publications during 1872-2015. Virol J. 2016;13:78.

20. Yi F, Yang $\mathrm{P}$, Sheng $\mathrm{H}$. Tracing the scientific outputs in the field of Ebola research based on publications in the Web of Science. BMC Res Notes. 2016;9:221.

21. Zyoud SH. Global research trends of Middle East respiratory syndrome coronavirus: a bibliometric analysis. BMC Infect Dis. 2016;16:255. 
22. Escobedo AA, Arencibia R, Vega RL, Rodriguez-Morales AJ, Almirall P, Alfonso M. A bibliometric study of international scientific productivity in giardiasis covering the period 1971-2010. J Infect Dev Ctries. 2015;9:76-86.

23. Zyoud SH, Al-Jabi SW, Sweileh WM. Worldwide research productivity in the field of electronic cigarette: a bibliometric analysis. BMC Public Health. 2014;14:667.

24. Zyoud SH, Al-Jabi SW, Sweileh WM, Awang R. A Scopus-based examination of tobacco use publications in Middle Eastern Arab countries during the period 2003-2012. Harm Reduct J. 2014;11:14.

25. Sweileh WM, Al-Jabi SW, Sawalha AF, AbuTaha AS, Zyoud SH. Bibliometric analysis of publications on Campylobacter: (2000-2015). J Health Popul Nutr. 2016:35:39.

26. Zyoud SH, Al-Jabi SW, Sweileh WM, Awang R, Waring WS. Global research productivity of $\mathrm{N}$-acetylcysteine use in paracetamol overdose: a bibliometric analysis (1976-2012). Hum Exp Toxicol. 2015;34:1006-16.

27. Zyoud SH, Al-Jabi SW, Sweileh WM, Al-Khalil S, Alqub M, Awang R. Global methaemoglobinaemia research output (1940-2013): a bibliometric analysis. Springerplus. 2015:4:626

28. Falagas ME, Pitsouni El, Malietzis GA, Pappas G. Comparison of PubMed, Scopus, Web of Science, and Google Scholar: strengths and weaknesses. FASEB J. 2008;22:338-42.

29. Lee RM, Moore LB, Bottazzi ME, Hotez PJ. Toxocariasis in North America: a systematic review. PLoS Negl Trop Dis. 2014;8:e3116.

30. Quattrocchi G, Nicoletti A, Marin B, Bruno E, Druet-Cabanac M, Preux PM. Toxocariasis and epilepsy: systematic review and meta-analysis. PLoS Negl Trop Dis. 2012;6:e1775

31. Fialho PM, Correa CR. A systematic review of toxocariasis: a neglected but high-prevalence disease in Brazil. Am J Trop Med Hyg. 2016;94:1193-9.

32. Thomson Reuters: 2014 Journal Citation Reports ${ }^{\circledR}$. 2015. http://www isiknowledge.com. Accessed 13 Nov 2015

33. Barriga OO. A critical look at the importance, prevalence and control of toxocariasis and the possibilities of immunological control. Vet Parasitol. 1988:29:195-234.

34. Beaver PC, Snyder CH, Carrera GM, Dent JH, Lafferty JW. Chronic eosinophilia due to visceral larva migrans; report of three cases. Pediatrics. 1952;9:7-19.

35. De Savigny $\mathrm{DH}$. In vitro maintenance of Toxocara canis larvae and a simple method for the production of Toxocara ES antigen for use in serodiagnostic tests for visceral larva migrans. J Parasitol. 1975;61:781-2.

36. de Savigny DH, Voller A, Woodruff AW. Toxocariasis: serological diagnosis by enzyme immunoassay. J Clin Pathol. 1979;32:284-8.

37. Del Prete GF, De Carli M, Mastromauro C, Biagiotti R, Macchia D, Falagiani P, Ricci M, Romagnani S. Purified protein derivative of Mycobacterium tuberculosis and excretory-secretory antigen(s) of Toxocara canis expand in vitro human T cells with stable and opposite (type $1 \mathrm{~T}$ helper or type $2 \mathrm{~T}$ helper) profile of cytokine production. J Clin Invest. 1991;88:346-50

38. Despommier D. Toxocariasis: clinical aspects, epidemiology, medical ecology, and molecular aspects. Clin Microbiol Rev. 2003;16:265-72.

39. Fisher M. Toxocara cati: an underestimated zoonotic agent. Trends Parasitol. 2003;19:167-70.

40. Glickman L, Schantz P, Dombroske R, Cypess R. Evaluation of serodiagnostic tests for visceral larva migrans. Am J Trop Med Hyg. 1978;27:492-8.

41. Glickman LT, Schantz PM. Epidemiology and pathogenesis of zoonotic toxocariasis. Epidemiol Rev. 1981;3:230-50.

42. Jacquier $P$, Gottstein B, Stingelin Y, Eckert J. Immunodiagnosis of toxocarosis in humans: evaluation of a new enzyme-linked immunosorbent assay kit. $J$ Clin Microbiol. 1991;29:1831-5.

43. Magnaval JF, Fabre R, Maurieres P, Charlet JP, de Larrard B. Application of the western blotting procedure for the immunodiagnosis of human toxocariasis. Parasitol Res. 1991;77:697-702.

44. Magnaval JF, Glickman LT, Dorchies P, Morassin B. Highlights of human toxocariasis. Korean J Parasitol. 2001;39:1-11.

45. Maizels RM, de Savigny D, Ogilvie BM. Characterization of surface and excretory-secretory antigens of Toxocara canis infective larvae. Parasite Immunol. 1984;6:23-37.

46. Overgaauw PA. Aspects of Toxocara epidemiology: human toxocarosis. Crit Rev Microbiol. 1997;23:215-31.

47. Overgaauw PA. Aspects of Toxocara epidemiology: toxocarosis in dogs and cats. Crit Rev Microbiol. 1997;23:233-51.
48. Rubinsky-Elefant G, Hirata CE, Yamamoto JH, Ferreira MU. Human toxocariasis: diagnosis, worldwide seroprevalences and clinical expression of the systemic and ocular forms. Ann Trop Med Parasitol. 2010;104:3-23.

49. Schantz PM. Toxocara larva migrans now. Am J Trop Med Hyg. 1989:41:21-34.

50. Shields JA. Ocular toxocariasis. A review. Surv Ophthalmol. 1984;28:361-81.

51. Taylor MR, Keane CT, O'Connor P, Mulvihill E, Holland C. The expanded spectrum of toxocaral disease. Lancet. 1988;1:692-5.

52. Wilder HC. Nematode endophthalmitis. Trans Am Acad Ophthalmol Otolaryngol. 1950;55:99-109.

53. Munoz-Urbano M, Lopez-Isaza AF, Hurtado-Hurtado N, Gomez-Suta D, Murillo-Abadia J, Delgado-Osorio N, Lagos-Grisales GJ, Villegas S, MedinaMorales DA, Rodriguez-Morales AJ. Scientific research in malaria: bibliometric assessment of the Latin-American contributions. Recent Pat Antiinfect Drug Discov. 2014;9:209-15.

54. Gonzalez-Alcaide G, Park J, Huamani C, Gascon J, Ramos JM. Scientific authorships and collaboration network analysis on Chagas disease: papers indexed in PubMed (1940-2009). Rev Inst Med Trop Sao Paulo. 2012:54:219-28.

55. Peng Y, Lin A, Wang K, Liu F, Zeng F, Yang L. Global trends in DEM-related research from 1994 to 2013: a bibliometric analysis. Scientometrics. 2015; 105:347-66.

56. Zhang L, Wang M-H, Hu J, Ho Y-S. A review of published wetland research, 1991-2008: ecological engineering and ecosystem restoration. Ecol Eng. 2010;36:973-80.

57. Liu X, Zhang L, Hong S. Global biodiversity research during 1900-2009: a bibliometric analysis. Biodivers Conserv. 2011:20:807-26.

58. Borecka A, Klapec T. Epidemiology of human toxocariasis in Poland - A review of cases 1978-2009. Ann Agric Environ Med. 2015;22:28-31.

59. Martin UO, Demonte MA. Urban contamination with zoonotic parasites in the central region of Argentina. Medicina (B Aires). 2008;68:363-6.

60. Ahmad B, Bhatti G, Thokar MA, Malla N. Human toxocariasis and ascariasis: concomitant parasitism in Srinagar, Kashmir, India. Indian J Pathol Microbiol. 2002:45:315-8.

61. Li T, Ho YS, Li CY. Bibliometric analysis on global Parkinson's disease research trends during 1991-2006. Neurosci Lett. 2008:441:248-52.

62. Zyoud SH, Al-Jabi SW, Sweileh WM, Awang R, Waring WS. Bibliometric profile of the global scientific research on methanol poisoning (1902-2012). J Occup Med Toxicol. 2015;10:17

63. Zyoud SH. Bibliometric analysis on global Catha edulis (khat) research production during the period of 1952-2014. Glob Health. 2015;11:39.

64. Zyoud SH, Al-Jabi SW, Sweileh WM, Al-Khalil S, Zyoud SH, Sawalha AF, Awang R. The Arab world's contribution to solid waste literature: a bibliometric analysis. J Occup Med Toxicol. 2015;10:35

\section{Submit your next manuscript to BioMed Central and we will help you at every step:}

- We accept pre-submission inquiries

- Our selector tool helps you to find the most relevant journal

- We provide round the clock customer support

- Convenient online submission

- Thorough peer review

- Inclusion in PubMed and all major indexing services

- Maximum visibility for your research

Submit your manuscript at www.biomedcentral.com/submit 